\title{
Raising Microbiology Research to the Next Level
}

\author{
Beniamino T. Cenci-Goga (D) \\ Dipartimento di Medicina Veterinaria, Laboratorio di Ispezione degli Alimenti di Origine Animale, \\ Università degli Studi di Perugia, 06126 Perugia, Italy; beniamino.cencigoga@unipg.it
}

Received: 8 December 2020; Accepted: 8 December 2020; Published: 9 December 2020

It is my great pleasure to introduce Microbiology Research under the new publisher, MDPI. This is a very special opportunity for us to utilize the strength of open access publications to publish original research, review articles, editorials, perspectives, case reports and brief reports to benefit microbiologists, physicians, veterinarians. The open access format allows manuscripts to be available to anyone seeking out the paper. It is always hard to restart a journal and especially one in the field of microbiology, where there are already many top-tiered journals. Our new goal is to develop this journal as one of the most respected journals in its field, and to receive an impact factor within the next two years. To achieve this goal, we rely on authors to submit their papers and publish on a regular basis, and on our editorial board members to ensure high-quality articles are published.

We are interested in both original research and review articles. Original research can be in any area of microbiology. Review articles are also of great interest to us.

Our first approach will be to set up two main sections: a "Clinical Microbiology" section, and a "Basic Microbiology Research" section. In a few months, several topical sections will be defined and led by a larger and restructured team of editors.

We look forward to a very productive year ahead of us and we appreciate all the work that our authors are putting in to make this a great journal.

Sincerely,

Beniamino T. Cenci-Goga, Editor-in-Chief of Microbiology Research.

Conflicts of Interest: The author declares no conflict of interest.

Publisher's Note: MDPI stays neutral with regard to jurisdictional claims in published maps and institutional affiliations.

(C) 2020 by the author. Licensee MDPI, Basel, Switzerland. This article is an open access article distributed under the terms and conditions of the Creative Commons Attribution (CC BY) license (http://creativecommons.org/licenses/by/4.0/). 